\title{
The Dilemma and Outlet of the Transformation and Upgrading of the Newly-built Applied Undergraduate Colleges
}

\author{
Deng Xiao-ni ${ }^{1, a}$, Dong Jun-fang ${ }^{2, b *}$ \\ 1 Wuhan Business University, Wuhan Economic and Technological Development zone, Wuhan, \\ Hubei, China \\ 2 Wuhan Business University, Wuhan Economic and Technological Development zone, Wuhan, \\ Hubei, China \\ adengxiaoni2004@163.com, b419185242@qq.com \\ ${ }^{*}$ Corresponding author
}

Keywords: Newly-built Applied Undergraduate Colleges; Transformation and Upgrading; Dilemma; Outlet

\begin{abstract}
Most new undergraduate colleges are upgraded from higher vocational colleges who are in the hope that the upgrading is the solution to the predicament of their development, and the fact is that the upgrading does not completely solve the problem, but gives rise to some new problems. There are two meanings of upgrading: the first refers to the transformation and upgrading from an academic-oriented college to an application-oriented one; the second refers to the quality and level of these colleges is to reach that of the undergraduate ones. The ways to enhance the transformation are as follows: to carry out discussions on application-oriented undergraduate education, and form research hotspots to deepen and systematize the research; to construct scientific and reasonable academic and research teams, and provide intellectual support for practice; to reach a consensus through argument and contends in the deep understanding of the problem; to construct high-quality teaching staff through teachers' ability promotion project.
\end{abstract}

\section{Introduction}

At present, with the second largest number of universities in the world, China now has the world's largest higher education system. By the end of May 2015, there were 2553 colleges and universities in China ${ }^{[1]}$ (including 447 private co-lleges, 275 independent colleges and 7 Sino-foreign cooperative educational schools). There are a lot colleges and universities of uneven quality and faculty's qualityy also varies. And the deployment rate of 403 newly-built undergraduate universities (excluding independent colleges) in the non-capital cities reached $57.82 \%{ }^{[2]}$. Since it might be hard for these newly-built undergraduate colleges t compete with universities with strong academic strength, they can only avoid the competitive edge by transforming into applications. In the meantime, in order to cultivate advanced applied talents this suits the environment of economic structural adjustment and industrial upgrading, solving the problems in China's higher education system, and to avoid homogenization in development, the government encourages those colleges to transform into application-oriented universities ${ }^{[3]}$.

\section{The dilemma of newly-built applied undergraduate colleges}

Newly-built undergraduate colleges usually share some common characteristics, such as short history, thus facing the transformation and upgrading demands in management, discipline construction, faculty construction etc. There are two folds in the so-called transformation and upgrading. One refers to transform from an academic-oriented college to an application-oriented one; the second refers to the quality and level of these colleges is to reach that of the undergraduate ones.

It is widely believed that it's rather easy for newly-built undergraduate colleges to transform into application-oriented ones since and they used to be vocational schools focusing on practical education. 
Yet it is not the case. Firstly, from a philosophical perspective, there are two means for universities to become legislative: "There are two major types of higher education philosophy. One is based on epistemology and the other is based on politics." [4]. Those holding an epistemological view believe that the primary function of the university is to fulfill the task of "departing complicated knowledge, analyzing and criticizing existing knowledge, and exploring new fields" [5]. For quite a long time, epistemological philosophy prevailed. Secondly, in China, the thought of "teaching weighs more than studies" has been deeply rooted. That is to say, taking the path into application-oriented development is more or less a decision that they had to make.

\subsection{The intrinsic limitation of newly-built applied undergraduate colleges}

Though with the responsibility of cultivating advanced applied talents before upgrading, newly-applied undergraduate colleges have their shortcomings.

First of all, the shortage of in-depth cooperation between schools and enterprises determines that they have some limitations in training applied talents. The prerequisite for running an application-oriented higher education institute is the combination of industry, education and research, which is usually based on cooperation between schools and enterprises. Without the joint mechanism of uniting enterprises and schools or the guidance of related policies, this kind of cooperation is usually conducted by schools only. Even with great enthusiasm to reach out for cooperation, colleges couldn't get equal response from companies. The reasons lie on the fact that for colleges, the cooperation is to cultivate talents suited in the market as well as deal with the difficulty of employment, while enterprises care more about profits. Enterprises may be more interested in the cooperation if colleges can provide new products or technology which is in fact the weakness of higher vocational colleges. Or if the shortage of manpower can be solved at that time, enterprises may also be willing to take part in. However, the fact is that companies nowadays have more opportunities to choose talents and even recruit more highly educated ones because of the difficulty of employment. At present, China's development mainly depends on economy. Enterprises can create profits and produce direct economic benefits, while colleges are not the direct benefits producer. Therefore, government places more emphasis on enterprises, and in that way companies hold a more favorable voice during the cooperation. In such an unequal situation, the cooperation is destined to be superficial and incomplete. And the fact that the shortage of many high-level applied talents development also shows that the education undertaken by the higher vocational colleges is far from meeting the goal. Thus, government is promoting the transformation of local undergraduate colleges into application-oriented ones.

Secondly, the formation and structure of faculty in higher vocational colleges leads to some limitations of fulfilling the task of cultivating applied talents. The faculty source in universities of China mainly includes graduates from ordinary colleges and universities, usually postgraduate students. The traditional teaching model in universities is theory-oriented, which determines the theory-oriented faculty. Due to the large scale of students in higher vocational colleges and the shortage of faculty, part-time teachers are hired mainly to reach the total teaching hours. But most part-time teachers would apply theoretical teaching and few would combine with practical teaching. Part-time teachers are insufficient in numbers and too flexible. Technically, the team of part-time teachers has not yet been established and it is hard to form a "double-certificated" (with teaching certification and professional certificate) faculty structure. Although some teachers in higher vocational colleges are encouraged to do some part-time work in companies, it is difficult to fundamentally deal with the disconnection between theoretical teaching and practical teaching.

Thirdly, the lack of scientific, normative and long-term professional curricular settings in higher vocational colleges has affected the cultivation of applied talents. The curricular structure in our country emphasizes "set as needed", which means what teachers teach whatever the market needs. But there are some drawbacks. To start with, it is too haste to set up certain majors without rigorous scientific demonstration. With the support of human resource database in various industries, 
the real needs of specific positions are unknown; therefore some major and curricular settings in colleges seem rather unsubstantial and thus doubtful. And it's easy to result in the repetition of major settings in various higher vocational colleges. Besides, the majors may soon become outdated once developed because of the lack of consideration in major settings at the first place. With the development of science and technology, the development and application of complex tools, humankind embarking on a fast track of development, the cycle of occupation and position becomes shorter and shorter due to the unsynchronized development of education cycles and economic cycles. Major settings require time to develop. So, it is likely that the prosperous period of some majors in college is, in fact, in the recession of related occupation and position. Apart from that, a lack of professional leaders and faculty in new majors makes it hard for colleges to cultivate talents required by certain occupations. Due to the reasons above, which is the source of college faculty, the existing faculty training model that both middle-aged senior teachers and young teachers are adapting to the teaching mode under the academic system, it's difficult to set up new majors. Let alone the phenomenon of "research inbreeding" that some teachers even copy textbooks compiled by well-known professors.

Finally, the management of higher vocational colleges has restricted the cultivation of applied talents. For one thing, the quality of administrative staff in higher vocational colleges need to be improved; for another, most of the higher vocational colleges are under the leadership of executive officials promoted by local governments. Due to various factors, they often deal with the affairs in an administrative way. At the same time, the shortage of experts or scholars with great social influence lead to academic power loses. All of these give a higher authority to the strong administrative power in higher vocational colleges, and their academic power is declining.

Higher vocational colleges often hope to get rid of the dilemma through upgrading. However, these problems would not be really solved after upgrading, instead there are some new problems. Therefore, some researchers refer to the newly-built application-oriented universities as "new universities" and compare them with the New Universities in the United Kingdom and the Land-grant Colleges in the United States. They argue that "new universities" in China guided by government policies and set in a top-down mode, is an upgrading on the original lower-level educational resources. In this way, the "new universities" are born with rejection reaction in education mode and faculty resources to develop application-oriented education ${ }^{[6]}$.

\subsection{The present difficulty of newly-built applied undergraduate colleges}

While we respect the historical background of the newly-built application-oriented universities, the actual difficulties should be paid more attention to. There are many difficulties in the development of these undergraduate colleges, and the key problem come from lack of research on application-oriented education (both theories and practice), the incompatibility of faculty' quality, structure and undergraduate education.

\subsubsection{The lack of research on application-oriented undergraduate education}

The lack of research results in the lack of theoretical ground for the newly-built application-oriented undergraduate colleges in practice. At present, there are two kinds of extreme tendencies in the practice of running application-oriented undergraduate colleges. One is vocationalizing undergraduate education. Students' engineering capacity and innovative ability are more emphasized while degrading the traditional education that emphasizes students' master of knowledge. So, it's often the case that colleges encourage the fragmentation of professional knowledge, arguing that theories are "only for practical use", while practical ability is over-emphasized. In this case, what professional theory is necessary for students to master, how much is enough remains unknown and unclear, and lack of research evidence. Thus, resulting in a difficult distinction between undergraduate education and vocational education; The other is theorization of application-oriented education. The fundamental reason is that there is short of deep understanding of the theory and practice of application-oriented education. The transformation and upgrading of newly-built 
application-oriented colleges is not only a realistic choice based on comprehensive assessment of conditions, but also the inevitable result of the promotion by national policies. The government encourages the upgrading based on two considerations. First, the popularization of higher education necessarily requires the diversification of colleges and universities; secondly, diversified and highly qualified talents pool are required to keep compatible with economic transformation and society development. From the existing research literature, the scholars mainly conduct research from a scientific frame work and analyze in a comprehensive way. However, problems like the definition of application-oriented education, how to conduct, whether there are academic standards and how to formulate these standards, whether there are academic standard and how to make these standard, is it a type of undergraduate universities, whether scientific research is needed, the differences and connections between application-oriented colleges and higher vocational education, the relationship between applicability and following the regulations of higher education and so on. Many of these deep-seated questions have not been truly solved, which shows the weakness in studies of application-oriented education theories and practical research. At the same time, with no application-oriented college in western countries, and little experience in China, there is nearly no model or theoretical reference in development and route of running application-oriented colleges. Thus they choose to dig into the definition of "application-oriented college", thinking that it is application-oriented higher education once the word "application" is added and put ahead of colleges. The international history of the development of higher education has shown that there is also a tendency from application-oriented education to traditional undergraduate education. For example, the New Universities in the UK eventually returned to the old route of traditional colleges and universities ${ }^{[7]}$. Some of the land grant colleges in the United States are also trying to return to traditional education. In addition, without scientific planning and classification guidance for the development of various kinds of colleges and universities, which to some extent reflects the insufficiency of theoretical research on higher education in China, it's still difficult to conduct scientific planning and classified guidance from the political level.

\subsubsection{The existing faculty organization is difficult to support major establishment and curriculum construction}

First, the lack of "double-qualified" teachers or the overall teambuilding of "double-qualified" faculty makes it hard to realize "application" in discipline and curriculum construction; secondly, teachers in these colleges are used to vocational education. The lack of undergraduate education background will lead to lack of such education philosophy and teaching experiences. They tend to apply the old teaching methods in higher vocational education instead of those suitable for undergraduate education, so it's difficult to achieve the respected outcome; Thirdly, the total number of faculty is usually insufficient, especially the number of professors, which is solved by recruiting a great many of graduates with $\mathrm{MA}$ of $\mathrm{PhD}$ and professors from other institutions. Although, the recruitment of professors is usually before the upgrading, little is completed afterwards. The newly recruited fresh graduates are young and less experienced, mainly based on theoretical teaching. They cannot, at least immediately, improve the structure of college faculty. Apart from that, it will also bring about new problems of an uneven age composition of the faculty. As the resources Limited, it is very difficult for these colleges to introduce high-level professors. Instead they mainly recruit professors from higher vocational colleges or other application-oriented colleges in developing cities (cities except for Beijing, Shanghai, Guangzhou) to meet the requirements. Research shows that lack of incentive and restraint mechanism for recruiting professors in some colleges will make no improvement in discipline and curriculum construction since the quality of high-level talents is no different than the original faculty.

\section{The means of upgrading into application-oriented colleges}

Transformation and upgrading are the necessary ways for the development of newly-built application-oriented colleges. The transformation is a complex systematic project that needs to 
be promoted in various aspects and at all levels, such as ideological understanding, school management, discipline construction, and faculty building, etc. Among them, there are two key primary problem need to be solved. One is the epistemological problem for application-oriented education, the second is the propriety between faculty quality and organization and application-oriented education.

\subsection{Carry out research and clarify the application of undergraduate education epistemology}

Theory is the forerunner of action. Without theoretical guidance, practice can only be aimless and blind, often with less accomplishment. For newly-built application-oriented undergraduate colleges, "application-oriented" is not just a conceptual change, but stands for its featured development by connecting colleges and local society and features. Its characteristics are originated from the development of regional feature and local economic society, without which the characteristics of new undergraduate colleges is hard to be presented.

The main reasons for the existing problems in the research of application-oriented undergraduate education (theory and practice) lie in the lack of a research atmosphere that scholars usually conduct research by themselves, which makes it difficult to form a systematic and in-depth research. Besides, the research is usually not practical enough. In view of this, the research on application-oriented undergraduate education (theory and practice) should be conducted with specific targets. Firstly, it is conducive to creating the atmosphere for the research of application-oriented undergraduate education in theories and practices, also forming the research hotspot, as well as driving the deepening of related fields and systematization of the results; Secondly it is conducive to form a diverse academic atmosphere, and through argument to clarify the deep-seated understanding problems in application-oriented undergraduate education, to reach a consensus, to construct the educational concept of running an application-oriented school, and connect the application-oriented development with the law of higher education; thirdly, it is conducive to building a team of academic and research echelon of combining theories and practices, to provide intellectual support and talents pool for the research of application-oriented educational in theories and practice. On this basis, it's necessary to establish the standards of the advanced application-oriented personnel in various industries. The academic standards are accustomed for different kinds of application-oriented colleges and universities according to industry standards; thus, these application-oriented colleges and universities can have a reference to put into practice.

\section{2 carry out capacity-building of new faculties to build high-quality faculty suitable for the development of application-oriented undergraduate colleges}

For colleges and universities, teachers are the mainstay of running a school. The level of faculty members reflects the academic level of colleges and universities, and determines the level of professional development and development of their disciplines. According to some research, the core factors affecting the competitiveness of colleges and universities mainly include four aspects: the quality of students, achievements in scientific research, faculty and disciplines, of which the team of teachers is the decisive factor. Application-oriented undergraduate institutions are no exception.

At present, for most of application-oriented undergraduate colleges in China, the foundation of discipline construction is weak and layout is single. In a word, the level of disciplinary construction is not satisfactory. The fundamental reason is that it's hard for the existing faculty team to support the discipline construction and development, which has already become a constrain in the development of these colleges and universities. Therefore, establishing a contingent of high-quality teachers with stable numbers, reasonable structures and strong competitiveness is the key to the successful transformation and upgrading of application-oriented undergraduate colleges. According to the current situation of faculty pool in these colleges, it is necessary to improve the ability of teachers and to make the structure of teachers and the quality of teachers suitable for the development of colleges. Firstly, it pays attention to the basic analysis, demand analysis and configuration analysis of 
teacher resources arrangement; Secondly, it formulates a scientific and reasonable faculty management system based on the scientific analysis of basic data, which includes recruitment system, training system, evaluation system, distribution system and security system. Only form an effective incentive and restraint mechanism through system management, can a sound environment both in policies and in management that is advantageous for teachers to upgrade themselves be created. Thirdly, it's necessary to formulate the academic standards (or quality standards) for teachers in application-oriented colleges and to recruit talents in strict accordance with the academic standards. To be more specific, the recruitment of high-level personnel is in urgent need, while the training and cultivating is mainly focused on existing faculty. In this way, the use of existing faculty and the recruitment of high-level talents can complement each other, to achieve the optimization of overall faculty structure, individual resources as well as academic collective composition.

\section{Acknowledgements}

This paper is supported by the key project of Wuhan Business University, "the Research on the Curr ent Situation of Linking Up and Upgrading of Applied Undergraduate Education and Higher Vocati onal Education" (Project No.: 2014008).

\section{References}

[1] Ministry of Education List of National Colleges and Universities in 2015. [EB\OL].http://www.moe.gov.cn/srcsite/A03/moe_634/201505/t20150521_189479.html.

[2] Wu Daguang. The third-party assessment of the higher education situation.[EB\OL]http://www.moe.gov.cn/jyb_xwfb/xw_fbh/moe_2069/xwfbh_2015n/xwfb_151 204/151204_sfcl/201512/t20151204_222888.html

[3] Ministry of Education, National Development and Reform Commission.Guiding Opinions on Guiding Local Colleges and Universities for Application-oriented Transition by Ministry of Finance. [EB\OL] http://www.moe.gov.cn/srcsite/A03/moe_1892/moe_630 /201511/t20151113_218942.htmlhttp://www.jyb.cn/zyjy/zyjyxw/201403/t20140304_572485.htm $\underline{l}$

[4] Bruckback (United States). Zheng Jiwei et al. (Translation). Higher Education Philosophy [M]. Hangzhou: Zhejiang Education Press, 1987 (07): 13.

[5] Bruckback (United States). Zheng Jiwei et al. (Translation). Higher Education Philosophy [M]. Hangzhou: Zhejiang Education Press, 1987 (07): 7.

[6] Liu Yourong. China's newly applied application-oriented undergraduate research [D]. Nanjing University .2011.2.11

[7] Gao Guijuan, Zhan Yingqiang.Changes in the Relationship Between British Universities and the Society - On the Orientation of University Development [J]. Modern University Education, 2004 (02): 63-66.

[8] Gu YongAn, Lu Zhenglin. An Important Judgment and Reflection on the Transformation and Development of Newly-built Undergraduate Colleges [J]. Vocational and Technical Education, $2012(11)$ 